\section{Conference information}

Many librarians have indicated a strong interest in becoming much more involved in the conferences held by other professional associations. Here, briefly, is information on three important 1993 conferences

\section{National Association for Chicano Studies}

The National Association for Chicano Studies' (NACS) 21st Annual Conference will be held March 25-27, 1993, at San Jose State University, California. The tentative theme of the conference is "Defining Chicana and Chicano Studies." Registration, hotel, and transportation information will be available by November 1992. The deadline for papers is December 31, 1992. Please request proposal forms early from: NACS 21 Program Committee, University of California, Berkeley, Chicano Studies Program, 3404 Dwinelle Hall, Berkeley, CA 94720. NACS membership information is available from: Rusty Barcelo, NACS Treasurer, Academic Affairs, 114 Jessup Hall, Univ. of Iowa, Iowa City, IA 52242.

Susana Hinojosa, University of Califormia, Berkeley, is chair of the ACRL Racial and Etbnic Diversity Committee

(Washington Hotline cont. from page 666) of Iowa is ideally suited for receipt of these funds." (S. Rept. 102-397)

LC \& GPO. The Library of Congress and the Government Printing Office would have been severely affected by a Senate-passed amendment to the Legislative Appropriations Bill. Offered by Senators Seymour (R-Calif.) and Brown (R-Colo.), the amendment would have cut funding in the bill by $15 \%$ over three years. With help from library constituent calls to key legislators, House-Senate conferees dropped the amendment. As it is, the final LC budget will not cover all mandatory cost increases.

Postal subsidies. The postal revenue forgone funding is $\$ 360$ million short of the amount the U.S. Postal Service estimated was needed to keep preferred and nonprofit rates at current levels. However, Congress provided a one-year "fix" which means these rates will

\section{National Association for Ethnic Studies}

The National Association for Ethnic Studies' (NAES) 1993 Conference will be held at the University of Utah, March 3-6, 1993. The conference theme is "Race, Class, and Gender." Additional conference information (a brochure will be available soon) is available from: 1993 NAES Conference, c/o Prof. Alberto Pulido, Conferences \& Institutes, University of Utah, 2174 Annex Bldg., Salt Lake City, UT 84112; phone: (801) 581-5809; fax: (810) 5813165 .

\section{National Conference on Racial \& Ethnic Relations in American Higher Education}

The 6th Annual National Conference on Racial \& Ethnic Relations in American Higher Education will be held in New Orleans, June 3-8, 1993. Request a conference brochure and information regarding conference presentations/ proposals from: Maggie Abudu Green, Executive Director, The Southwest Center for Human Relations Studies, University of Oklahoma, 555 Constitution, Norman, OK 73037-0005; phone: (405) 325-3936; fax: (405) 325-1824.

not increase during FY93. For the first time, a cross subsidy has commercial mailers subsidizing the difference- - very unsatisfactory and interim resolution of the annual shortfall dilemma. Appropriators called for permanent legislative reform.

(Preservation News cont. from page 668)

\section{ACRL/NEC convenes Preservation/ Conservation Interest Group}

The Board of ACRL's New England Chapter has authorized creation of a Preservation/Conservation Interest Group intended to provide a forum for library preservation administrators, particularly those who have responsibility for circulating collections. The first meeting will be held at 10:00 a.m. On November 12, 1992, at the Wellesley College Library. For more information or to register for the first meeting, please contact the editor of this column. 